\begin{tabular}{|lll|}
\hline Diterima & $:$ & 3 November 2020 \\
Direvisi & $:$ & 2 Februari 2021 \\
Disetujui & $:$ & 25 April 2021 \\
Diterbitkan & $:$ & 27 April 2021 \\
\hline
\end{tabular}

\title{
PENERAPAN METODE MATERNAL REFLEKTIF (MMR) UNTUK MENINGKATKAN KEMAMPUAN MEMBACA PEMAHAMAN PADA SISWA DENGAN HAMBATAN PENDENGARAN
}

\author{
Tiana Putri ${ }^{1}$, Murni Winarsih ${ }^{2} \&$ Trisna Mulyeni ${ }^{3}$ \\ e-mail: tianaputri04@gmail.com ${ }^{1}$, winarsih.murni@yahoo.com², \\ mulyeni.students@gmail.com ${ }^{3}$ \\ Program Studi Pendidikan Khusus, Fakultas Ilmu Pendidikan, \\ Universitas Negeri Jakarta \\ Jalan Rawamangun Muka Raya, RT.11/RW.14, Rawamangun, Kec. Pulo Gadung, Kota Jakarta \\ Timur, Daerah Khusus Ibukota Jakarta 13220
}

\begin{abstract}
Abstrak: Penelitian tindakan kelas ini bertujuan untuk meningkatkan kemampuan membaca pemahaman siswa dengan hambatan pendengaran melalui penerapan Metode Maternal Reflektif (MMR) dalam pembelajaran. Berdasarkan hasil observasi dan hasil tes kemampuan awal yang dilakukan pada siswa dengan hambatan pendengaran kelas IV di SLB yang menjadi partisipan penelitian, dapat dilihat bahwa kemampuan membaca pemahaman siswa masih perlu ditingkatkan. Penelitian ini merupakan penelitian tindakan kelas. Partisipan dalam penelitian ini terdiri dari 1 siswa laki-laki dan 3 siswa perempuan. Penelitian dilakukan dalam dua siklus, dalam setiap siklus terdiri dari 4 tahapan yaitu perencanaan, pelaksanaan, pengamatan, dan refleksi. Metode dalam pengumpulan data berupa observasi kelas, tes kemampuan membaca pemahaman, dan dokumentasi data pelengkap. Hasil penelitian menunjukkan bahwa penerapan MMR dalam pembelajaran dapat meningkatkan kemampuan membaca pemahaman siswa dengan hambatan pendengaran secara signifikan.
\end{abstract}

Kata-kata Kunci: hambatan pendengaran, membaca pemahaman, metode maternal reflektif, siswa SLB

\section{APPLICATION OF MATERNAL REFLECTIVE METHODS TO IMPROVE READING COMPREHENSION FOR STUDENTS WITH HEARING IMPAIRMENTS}

\begin{abstract}
The purpose of this classroom action research was to improve the reading comprehension of students with hearing impairments through the application of Maternal Reflective Methods (MMR) in the learning activity. Based on the results of observations and initial tests on students with hearing impairment in grade 4 of school for students with disabilities, it is evident that students reading comprehension skills need to be improved further. The Maternal Reflective Method is utilized to improve reading comprehension for students with hearing impairments. The research participants consisted of a male and three females with hearing impairment students. The research was held in two cycles. Each cycle consists of 4 stages: planning, implementation, observation, and reflection. The data were obtained through classroom observation, reading comprehension tests, and supplementary documents. The results showed that the utilization of the Maternal Reflective Method in learning activity could significantly improve reading comprehension for students with hearing impairments.
\end{abstract}

Keywords: hearing impairment, reading comprehension, maternal reflective methods, students of school for students with disabilities 


\section{PENDAHULUAN}

Penyelenggaraan pendidikan di Sekolah Luar Biasa (SLB) tingkat dasar ditujukan sebagai peletak dasar konsep ilmu pengetahuan. Konsep dasar ilmu pengetahuan merupakan modal bagi siswa dalam mengembangkan ilmu pengetahuan tingkat lanjut. Pada tingkat sekolah dasar (SD), salah satu yang harus ditingkatkan pada siswa adalah pelajaran Bahasa Indonesia. Bahasa Indonesia merupakan salah satu mata pelajaran yang memiliki peranan penting dalam dunia pendidikan, sampai pada kehidupan sehari-hari, Bahasa Indonesia digunakan sebagai sarana komunikasi baik secara lisan maupun tulisan. Pelajaran Bahasa Indonesia juga dinilai sangat penting dalam mengembangkan keterampilan berbahasa. Keterampilan berbahasa meliputi empat aspek yaitu kemampuan menyimak, kemampuan berbicara, kemampuan membaca, dan kemampuan menulis.

Menyimak merupakan proses mendengarkan lambang-lambang lisan dengan penuh perhatian, pemahaman, apresiasi, dan interpretasi untuk memperoleh informasi serta memahami makna komunikasi yang telah disampaikan oleh pembicara melalui ujaran dan bahasa lisan (Tarigan, 2015). Sedangkan berbicara yaitu kemampuan mengucapkan bunyi-bunyi bahasa untuk mengekspresikan atau menyampaikan pikiran, gagasan, dan perasaan secara lisan (Tarigan, 1992). Bagi siswa dengan hambatan pendengaran, kemampuan menyimak dilakukan melalui indera penglihatan, sehingga apa yang disimaknya seringkali berbeda dengan maksud sebenarnya. Kemampuan membaca perlu dimaksimalkan oleh siswa dengan hambatan pendengaran. Dengan membaca siswa dapat menyimak informasi melalui tulisan serta dapat melatih kemampuan berbicaranya.

Membaca adalah suatu kegiatan yang sangat berguna dalam kehidupan sehari-hari. Membaca merupakan proses pemerolehan pesan atau informasi yang diterima oleh pembaca baik secara lisan maupun tulisan (Tarigan, 2015). Membaca merupakan keterampilan melisankan dan mempersepsi bahasa tulis untuk memperoleh pesan yang disampaikan (Tim Guru SLB B Pangudi Luhur, 2013). Kegiatan membaca dilakukan untuk memperoleh makna yang tepat dari suatu isi bacaan. Membaca pada hakikatnya merupakan suatu kegiatan yang tidak hanya sekedar melafalkan tulisan, melainkan melibatkan aktivitas visual, berpikir, psikolinguistik, dan metakognitif (Rahim, 2008). Salah satu dimensi keterampilan membaca adalah membaca pemahaman.
Membaca pemahaman merupakan proses pemerolehan makna secara aktif dengan melibatkan pengetahuan dan pengalaman yang dimiliki oleh pembaca serta dihubungkan dengan isi bacaan (Somadyo,2017). Membaca pemahaman juga dapat dimaksudkan sebagai istilah yang digunakan untuk kegiatan membaca yang bertujuan untuk memperoleh informasi yang terkandung dalam teks bacaan (Abidin, 2012). Keterampilan memahami isi bacaan merupakan seluruh kemampuan dalam memahami apa yang telah dibaca. Tujuan utama membaca pemahaman adalah memperoleh pemahaman. Kemampuan membaca pemahaman sudah mulai dioptimalkan pada jenjang kelas 3 SD. Badan Standar Nasional Pendidikan (2006) menyatakan bahwa pembelajaran membaca dalam kurikulum pendidikan Bahasa Indonesia merupakan salah satu pokok bahasan yang diajarkan di tingkat Sekolah Dasar. Tujuannya agar siswa mampu mencari sumber, mengumpulkan, menyaring, dan menyerap informasi dari bacaan. Oleh karena itu, pengajaran membaca perlu diajarkan pada anak-anak khususnya anak usia Sekolah Dasar (Harefa, dkk., 2019).

Kemampuan berbahasa anak didasari pada tingkat pendidikannya. Pada tingkat kelas IV SD hingga Sekolah Menengah, siswa berada pada tahapan di mana siswa akan lebih mudah menyerap informasi media bacaan baik itu cetak maupun digital berupa narasi, deskripsi, cerita hingga definisi dan dapat disimpulkan (Santrock, 2007). Kemampuan memahami isi dari suatu bacaan menjadi penting karena dapat dijadikan bekal dan kunci keberhasilan dalam proses pendidikan. Pentingnya membaca tidak dibatasi untuk siswa pada umumnya saja. Siswa berkebutuhan khusus pun membutuhkan kemampuan membaca, khususnya individu dengan hambatan pendengaran.

Individu dengan hambatan pendengaran adalah seseorang yang mengalami gangguan dalam kemampuan mendengar yang berdampak pada terjadinya kemiskinan bahasa. Mereka mengalami kesulitan dalam mengenal lambang bahasa atau nama guna mewakili suatu benda, kegiatan, peristiwa, dan perasaan, serta dalam memahami aturan atau sistem bahasa yang berlaku (Budiyanto, 2018). Seringkali mereka mengalami salah persepsi dalam berkomunikasi. Hal ini merupakan dampak dari keterbatasan dalam ketajaman pendengaran, sehingga individu dengan hambatan pendengaran mengalami keterbatasan dalam menerima informasi dan mengalami dampak yang signifikan dalam kehidupannya. Informasi yang didapat melalui indra pendengarannya sangat sedikit sehingga individu 
dengan hambatan pendengaran lebih memanfaatkan indra penglihatannya. Salah satunya adalah dengan kegiatan membaca.

Pada siswa dengan hambatan pendengaran, kemampuan membaca perlu diajarkan secara optimal agar siswa dapat memperoleh informasi dari bacaan atau tulisan yang ia baca sesuai dengan makna yang terkandung dalam bacaan atau tulisan tersebut. Kemampuan siswa dalam membaca pemahaman juga sangat penting untuk menunjang kegiatan pembelajaran agar menjadi optimal. Pada umumnya, evaluasi pembelajaran dilakukan dengan memberikan tes berupa soal-soal latihan. Dalam soal-soal latihan seringkali terdapat teks bacaan yang menuntut siswa untuk membaca dan memahami isi bacaan tersebut. Jika kemampuan membaca siswa tidak dioptimalkan dengan baik, maka siswa akan mengalami kesulitan dalam mengerjakan soal-soal latihan tersebut.

Selain itu, siswa yang mengalami hambatan dalam kemampuan membaca pemahaman, seringkali mengalami kesalahpahaman dalam memperoleh informasi. Hal ini diperkuat dengan adanya hasil observasi yang dilakukan pada Bulan Januari hingga Juni 2020 di sebuah SLB Negeri di Kota Cirebon Jawa Barat, yang berkaitan dengan kemampuan membaca pemahaman pada siswa dengan hambatan pendengaran kelas IV. Kemampuan membaca pemahaman yang masih rendah terlihat pada saat guru memberikan pertanyaan terkait isi bacaan yang telah dibaca bersama, siswa terlihat bingung dan ragu-ragu untuk menjawab. Dalam hal ini terlihat bahwa siswa masih belum memahami isi bacaan atau informasi yang telah ia baca. Keraguan siswa dalam menjawab soal menunjukkan ketidakpercayaan diri siswa akibat keterbatasannya dalam memperoleh informasi dan rendahnya daya abtraksi siswa hambatan pendengaran, sehingga mereka sulit memahami isi dari suatu bacaan. Selain itu, pembelajaran yang kurang interaktif yaitu penggunaan metode pembelajaran yang konvensional berupa metode ceramah (pembelajaran terpusat pada guru) membuat siswa nampak kurang maksimal dalam kegiatan pembelajaran.

Berdasarkan kenyataan di lapangan, cara untuk mengatasi masalah ini dapat digunakan Metode Maternal Reflektif (MMR) untuk meningkatkan kemampuan membaca pemahaman siswa dengan hambatan pendengaran kelas IV di SLB yang menjadi lokasi penelitian. MMR merupakan metode pembelajaran yang meniru cara seorang ibu dalam mengajarkan anaknya dari yang tidak bisa menjadi bisa. Hal ini juga didukung dengan adanya penelitian terdahulu oleh Zulmiyetri (2017) tentang MMR untuk meningkatkan kemampuan bahasa lisan anak tunarungu, kemudian penelitian dari Irwanto, dkk. (2018) tentang efektivitas MMR dalam meningkatkan kemampuan bahasa anak tunarungu, serta penelitian dari Rizkia (2014) tentang peningkatan kemampuan membaca pemahaman melalui MMR.

Penelitian ini memilih MMR karena memiliki keunggulan yang dirasa mampu meningkatkan kemampuan membaca pemahaman pada siswa dengan hambatan pendengaran di SLB. Menurut Griffey dalam Bunawan \& Yuwati (2000), MMR merupakan metode yang menggabungkan aspek terbaik dari metode natural dan struktural. MMR yaitu pemerolehan kemampuan berbahasa anak dengan hambatan pendengaran yang meniru seorang ibu bercakap-cakap dengan anaknya, dengan frekuensi yang tinggi sehingga anak mampu berbahasa (Pangudi Luhur, 2013). MMR juga bercirikan hal-hal berikut: bertolak pada minat dan kebutuhan siswa dan bukan pada program pembelajaran tentang aturan bahasa yang perlu di-drill, menyajikan bahasa yang sewajar dan sesederhana mungkin, baik secara ekspresif maupun reseptif serta menuntun siswa agar secara bertahap menemukan sendiri aturan atau bentuk bahasa melalui refleksi terhadap segala pengalaman berbahasanya. Secara umum, tahapan MMR terdiri dari 1) Perdati, 2) Percami, 3) Refleksi, 4) Percali (Pangudi Luhur,2013). Penerapan MMR diharapkan dapat meningkatkan pemahaman siswa dengan hambatan pendengaran dalam memahami isi atau informasi dari suatu bacaan.

\section{METODE PENELITIAN}

Penelitian ini merupakan penelitian tindakan kelas yang di dalamnya mencakup pendekatan kualitatif dan kuantitatif. O'Brien dalam Mulyatiningsih (2011) menyatakan bahwa penelitian tindakan kelas (PTK) dilakukan pada sekelompok orang yang diidentifikasi permasalahannya, kemudian peneliti menetapkan suatu tindakan untuk mengatasinya. Data kualitatif dan kuantitatif digunakan untuk mengetahui hasil peningkatan kemampuan membaca pemahaman siswa hambatan pendengaran kelas IV di SLB, yang dipilih karena terdapat siswa hambatan pendengaran yang memiliki karakteristik sesuai dengan subjek penelitian yaitu perlu adanya peningkatan dalam kemampuan membaca pemahaman serta sekolah yang dijadikan tempat penelitian belum pernah menerapkan metode yang akan diterapkan dalam penelitian yaitu MMR.

Penelitian dilaksanakan pada Bulan Januari 
sampai Juni 2020. Partisipan penelitian berjumlah 4 orang, yaitu seorang siswa laki-laki dan 3 orang siswa perempuan. Data penelitian yang digunakan dalam penelitian ini adalah kuantitatif dan kualitatif. Instrumen penelitian berupa hasil tes kemampuan siswa dalam mengerjakan soal tes membaca pemahaman, dan hasil pengamatan (observasi) selama proses pembelajaran berlangsung berupa respons, situasi, serta keadaan siswa terhadap penerapan MMR dalam meningkatkan kemampuan membaca siswa. Pengamatan yang dilakukan juga berupa peningkatan kemampuan membaca pemahaman anak dalam proses identifikasi langsung dan tidak langsung pada tahap percakapan membaca ideovisual (percami).

Teknik analisis data yang digunakan dalam penelitian ini adalah data proses dan tindakan yang bersifat kualitatif dan kuatitatif. Analisis data kualitatif berupa hasil pengamatan saat melakukan tindakan. Untuk menganalisis hasil pengamatan selama tindakan, dapat dilakukan langkah sebagai berikut: 1) Pengumpulan data, 2) Reduksi dan kategorisasi data, 3) Display data, 4) Penarikan kesimpulan, seperti digambarkan pada gambar 1 berikut ini.

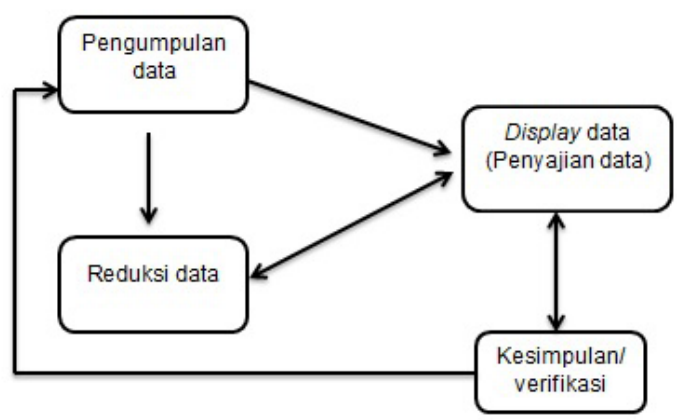

Gambar 1. Skema Analisis Data Kualitatif

Sedangkan analisis data kuantitatif diperoleh melalui tes pada setiap siklusnya. Untuk menghitung nilai kemampuan siswa, peneliti menggunakan rumus sebagai berikut:

Nilai Keberhasilan $=\frac{\text { Skor yang diperoleh }}{\text { Skor maksimal }} \times 100$

\section{HASIL DAN PEMBAHASAN}

Hasil penelitian mengenai peningkatan kemampuan membaca pemahaman siswa hambatan pendengaran kelas IV di SLB disajikan dalam bentuk tabel, grafik dan deskripsi yang diharapkan dapat mudah dipahami dan dimengerti.

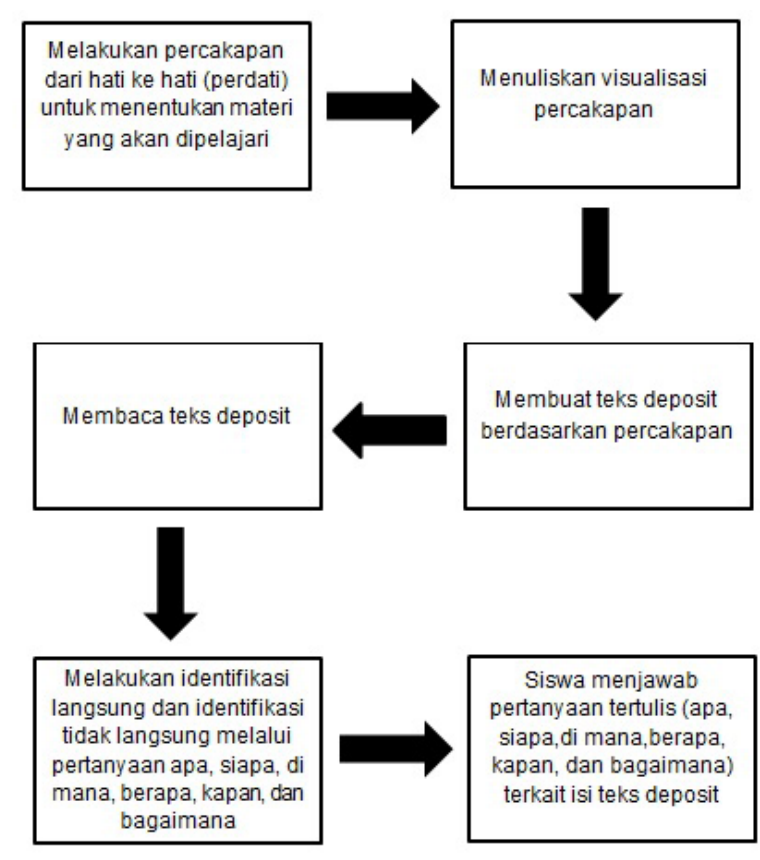

Gambar 2. Langkah-Langkah Melakukan Kegiatan Membaca Pemahaman Pada Siswa dengan Hambatan Pendengaran Menggunakan MMR

Sebelum melakukan tindakan siklus I, guru memberikan pre-test kepada siswa. Pre-test dilakukan untuk mengetahui kemampuan awal membaca pemahaman sebelum dilakukan tindakan. Kemampuan awal siswa merupakan kemampuan yang dimiliki siswa sebelum dilakukan tindakan berupa penerapan MMR. Pengamatan kemampuan awal membaca pemahaman ini dilakukan dengan memberikan pre-test berupa teks bacaan yang disertai dengan soal yang harus dijawab oleh siswa terkait bacaan yang tersedia. Hasil Pre-test sebagai berikut:

Tabel 1.

Hasil Pre-test Kemampuan Membaca Pemahaman Siswa dengan Hambatan Pendengaran

\begin{tabular}{cccc}
\hline No & Inisial & $\begin{array}{c}\text { Nilai Kemampuan Awal } \\
\text { Membaca Pemahaman }\end{array}$ & KKM \\
\hline 1. & YS & 50 & \\
2. & FR & 50 & 70 \\
3. & FZ & 40 & \\
4. & SL & 20 & \\
\hline
\end{tabular}

Hasil awal kemampuan membaca pemahaman siswa hambatan pendengaran kelas IV di SLB menunjukkan bahwa perlu adanya peningkatan dalam kemampuan membaca pemahaman. Nilai tertinggi yang diperoleh dari hasil awal adalah 50, sedangkan terendahnya adalah 20. Semua siswa mendapatkan nilai di bawah kriteria nilai yang ditentukan yaitu 70. Sebelum penerapan MMR, guru menggunakan metode ceramah dan penugasan dalam pembelajaran. 
Setelah mengetahui kemampuan awal siswa, barulah dilakukan tindakan pembelajaran menggunakan MMR pada siklus pertama. Tahapan kegiatan pembelajaran MMR yang dilakukan yaitu tahap perdati, percami, dan refleksi. Pada kegiatan perdati, siswa diajak untuk mengeksplorasi pengetahuan dan gagasan yang dimilikinya mengenai topik yang sedang dibahas. Kemudian pada tahap percami, siswa melakukan identifikasi langsung dan tidak langsung terhadap teks deposit yang telah dibuat oleh guru berdasarkan kegiatan perdati. Setelah itu barulah dilakukan refleksi terhadap pokok bahasan. Pada setiap akhir siklus, akan dilakukan post-test. Post-test dilakukan untuk melihat hasil kemampuan membaca pemahaman setelah dilakukan tindakan pembelajaran menggunakan MMR pada siswa dengan hambatan pendengaran kelas IV SLB.

Tabel 2.

Hasil Post-test Siklus I Kemampuan Membaca Pemahaman Siswa dengan Hambatan Pendengaran Kelas IV SLB

\begin{tabular}{cccc}
\hline No & Inisial & $\begin{array}{c}\text { Nilai Kemampuan } \\
\text { Membaca Pemahaman }\end{array}$ & KKM \\
\hline 1. & YS & 100 & \\
2. & FR & 100 & 70 \\
3. & FZ & 90 & \\
4. & SL & 80 & \\
\hline
\end{tabular}

Berdasarkan tabel di atas, menunjukkan bahwa semua siswa mengalami peningkatan hasil dalam kemampuan membaca pemahaman dengan nilai tertinggi adalah 90 dan nilai terendah adalah 60. Meskipun semua siswa mengalami peningkatan hasil, namun masih ada 2 siswa yang nilainya masih berada di bawah kriteria nilai yang ditentukan, sehingga dilakukan tindakan pada siklus kedua. Pada siklus kedua, semua siswa sudah semakin terbiasa dengan MMR. Guru juga memberikan pengalaman langsung (pergi ke taman sekolah, kolam ikan, dll) kepada siswa dalam menciptakan topik yang hendak dibahas. Berikut adalah hasil kemampuan membaca pemahaman setelah dilakukan tindakan pada siklus II.

Tabel 3.

Hasil Post-test Siklus II Kemampuan Membaca Pemahaman Siswa dengan Hambatan Pendengaran Kelas IV SLB

\begin{tabular}{cccc}
\hline No & Partisipan & $\begin{array}{c}\text { Nilai Kemampuan } \\
\text { Membaca Pemahaman }\end{array}$ & KKM \\
\hline 1. & YS & 90 & \\
2. & FR & 80 & 70 \\
3. & FZ & 60 & \\
4. & SL & 60 & \\
\hline
\end{tabular}

Berdasarkan tabel, dapat dilihat bahwa pada siklus II nilai semua siswa sudah memenuhi kriteria nilai yang ditentukan dengan nilai tertinggi adalah 100 dan nilai terendahnya adalah 80. Untuk mengetahui lebih jelas peningkatan hasil kemampuan membaca pemahaman yang diperoleh oleh siswa hambatan pendengaran kelas IV SLB, tabel dan grafik peningkatannya sebagai berikut:

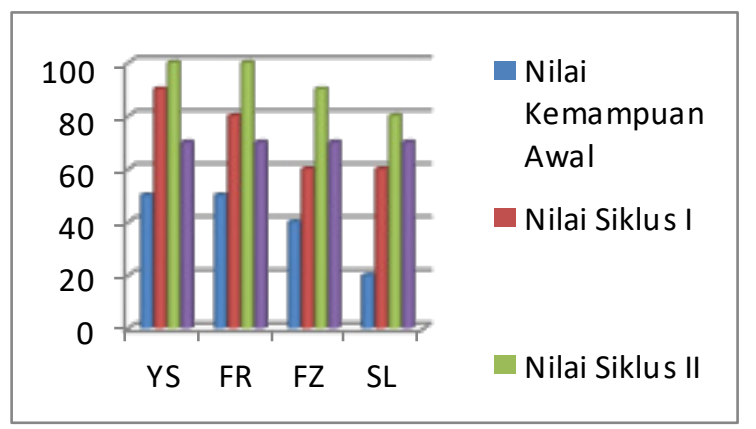

Gambar 3. Grafik Peningkatan Hasil Kemampuan Membaca Pemahaman Siswa dengan Hambatan Pendengaran Kelas IV SLB

Berdasarkan grafik di atas, terlihat bahwa semua siswa sudah mengalami peningkatan kemampuan membaca pemahaman dan sudah memenuhi skor penilaian yang ditentukan yaitu 70. Pada hasil evaluasi siklus II, YS dan FR mampu menjawab semua pertanyaan dengan benar sehingga mendapatkan nilai sempurna 100. Sedangkan untuk FZ, ia sudah mengalami peningkatan yang sangat baik bila dibandingkan dengan hasil kemampuan awal dan siklus I. pada siklus II, FZ memperoleh nilai 90. FZ hanya kurang tepat saat menjawab pertanyaan nomor 5. Sedangkan SL mendapatkan nilai 80 pada evaluasi di siklus II. SL kurang tepat dalam menjawab pertanyaan nomor 3 dan 5. Namun bila dibandingkan dengan tes kemampuan awal dan evaluasi pada siklus I, kemampuan SL berdasarkan hasil evaluasi pada siklus II sudah banyak mengalami peningkatan. Berdasarkan hasil tersebut, kemampuan membaca pemahaman siswa sudah meningkat dan memenuhi nilai yang telah ditentukan.

\section{Pembahasan}

Setelah dilakukan tindakan pada siklus I dan siklus II serta evaluasi pada setiap siklusnya, maka akan dilakukan analisis terhadap peningkatan kemampuan membaca pemahaman siswa dengan hambatan pendengaran kelas IV dengan menerapkan MMR pada kegiatan pembelajarannya.

Pada pertemuan awal proses pembelajaran dengan menggunakan MMR, siswa masih harus banyak melakukan penyesuaian terhadap tahapan 
kegiatan yang dilakukan saat pembelajaran. Terutama saat kegiatan bercakap. Dalam masa penyesuaian penerapan MMR kepada siswa, guru setiap hari membawa benda-benda yang kemudian sengaja diletakkan di atas meja. Hal tersebut bertujuan agar siswa dapat tertarik pada suatu benda dan dapat mempercakapkan sebagai materi pembelajaran. Guru juga seringkali meminta siswa untuk membawa benda atau melakukan kegiatan di rumah atau di sekolah yang bertujuan agar saat percakapan semua siswa dapat mengungkapkan gagasannya.

Pada proses tindakan siklus I, guru masih harus menggunakan isyarat sebagai komunikasi tambahan baik saat proses perdati maupun percami. Saat percami guru juga masih sering membantu siswa dalam menemukan jawaban dengan memberikan beberapa petunjuk terkaitan isi bacaan.

Pada pertemuan pertama siklus I, beberapa siswa masih perlu bimbingan dalam melakukan percakapan dan menjawab pertanyaan yang sesuai dengan isi bacaan. Meskipun demikian, semua siswa sangat berantusias dan berusaha untuk menjawab pertanyaan dengan baik. Pada pertemuan ketiga, semua siswa sudah mulai menyesuaikan diri dengan cukup baik. Siswa sudah mau berekspresi saat bercakap serta sangat berantusias saat menjawab pertanyaan secara lisan.

Pada pertemuan berikutnya di siklus I, siswa mulai berperan aktif secara mandiri dalam percakapan, menjawab pertanyaan lisan, mencari tulisan, dan mengerjakan tugas dari guru. Pada siklus I, hasil yang diperoleh setelah dilakukan evaluasi adalah semua siswa mengalami peningkatan. Namun, hanya 2 dari 4 siswa yang sudah memenuhi Kriteria Ketuntasan Minimal (KKM). Nilai tertinggi yang didapat adalah 90. Sedangkan nilai terendah yang didapat adalah 60 .

Belum tercapainya keberhasilan pada siklus I disebabkan oleh beberapa kendala saat pelaksanaan tindakan. Kendala-kendala tersebut di antaranya, siswa memerlukan penyesuaian dalam pembelajaran menggunakan MMR, beberapa siswa seringkali mengobrol sendiri dan tidak memperhatikan pelajaran, saat kegiatan pembelajaran terkadang ada siswa yang berselisih hingga salah satunya ada yang marah atau menangis, siswa dari kelas lain sering mengganggu pelajaran dengan tiba-tiba masuk ke ruang kelas, mematikan lampu kelas, atau mengintip dari luar jendela. Meskipun terdapat beberapa kendala, tetapi adapula kelebihan-kelebihan yang ditemukan selama proses pelaksanaan siklus I diantaranya adalah, siswa menjadi lebih aktif berpartisipasi dalam pembelajaran, siswa tampak berantusias dalam pembelajaran terutama dalam kegiatan percami saat siswa menjawab dan berebut untuk maju kedepan menemukan kata atau kalimat, siswa juga dapat belajar menangkap dan memahami apa yang diungkapkan oleh lawan bicaranya.

Pada pelaksanaan pembelajaran di siklus II, semua siswa sudah terbiasa dengan MMR. Sehingga semua siswa sudah memahami alur kegiatan yang akan dilakukan selama pembelajaran. Siswa juga sudah berperan aktif berpartisipasi dalam menciptakan topik percakapan. Pada siklus II, siswa sudah dapat memahami pertanyaan-pertanyaan secara lisan dengan baik. Siswa sudah mulai memahami jawaban dari pertanyaan yang diajukan seperti pertanyaan "di mana" jawabannya berupa tempat, pertanyaan "kapan" jawabannya berupa waktu begitu juga pertanyaan siapa, apa, berapa, dan bagaimana.

Hasil evaluasi pada siklus II menunjukkan bahwa semua siswa mengalami peningkatan dan sudah memenuhi Kriteria Ketuntasan Minimal (KKM). Nilai tertinggi didapatkan oleh YS dan FR yaitu 100. Sedangkan nilai terendahnya didapatkan oleh SL yaitu 80. Dengan demikian penelitian ini telah membuktikan bahwa kemampuan membaca pemahaman siswa hambatan pendengaran dapat ditingkatkan dengan MMR dan mendapatkan pengalaman yang sama.

Berdasarkan data observasi monitoring partisipasi siswa menunjukkan adanya peningkatan skor partisipasi siswa pada siklus II dibandingkan dengan siklus I. Hasil observasi partisipasi siswa pada siklus II adalah sebagai berikut: YS mendapatkan skor 90 dengan kriteria sangat baik, FR mendapatkan skor 94 dengan kriteria sangat baik, FZ mendapatkan skor 74 dengan kriteria baik, dan SL mendapatkan skor 76 dengan kriteria baik. Jika dibandingkan dengan skor pada siklus I, pada siklus II skor semua siswa mengalami peningkatan. YS pada siklus I mendapatkan skor 76 kemudian meningkat menjadi 90 pada siklus II, FR mendapatkan skor 80 pada siklus I kemudian meningkat menjadi 94 pada siklus II, FZ memperoleh skor 70 pada siklus I kemudian meningkat menjadi 74 pada siklus II, dan SL mendapatkan skor 72 pada siklus I kemudian meningkat pada siklus II menjadi 76.

Hal tersebut menunjukkan bahwa penerapan MMR dapat meningkatkan motivasi siswa dalam pembelajaran. Siswa menjadi lebih aktif dalam mengungkapkan ide, menyanggah, dan menjawab pertanyaan dari lawan bicaranya.Kemampuan membaca pemahaman didukung dengan kemampuan bahasa reseptif yang baik. Kemampuan bahasa reseptif yang baik akan mempermudah siswa dalam penguasaan berbahasa selanjutnya. 
Dalam penelitian ini, kemampuan membaca pemahaman dikembangkan melalui pemahaman isi percakapan melalui oral atau membaca bibir saat percakapan dan pemahaman bacaan sesuai dengan pengalaman anak. Berdasarkan penelitian yang dilakukan, MMR memiliki banyak kelebihan bagi siswa dengan hambatan pendengaran karena materi pembelajaran yang diterapkan didapatkan berdasarkan pengalaman yang dialami siswa, sehingga dapat membantu meningkatkan kemampuan membaca pemahaman bagi siswa. Selain itu, MMR juga dapat dijadikan model pembelajaran bagi siswa dengan hambatan pendengaran dalam memperoleh bahasa. Karena apa yang diungkapkan anak melalui isyarat akan dibahasakan kembali oleh guru, sehingga siswa mampu memahami pengucapan yang mereka ungkapkan melalui isyarat.

Tindakan yang dilakukan dengan menggunakan MMR dalam meningkatkan kemampuan membaca pemahaman siswa hambatan pedengaran secara prosesnya dilakukan mengikuti langkah-langkah MMR mulai dari tahap perdati, tahap percami, dan refleksi. Untuk mendukung kegiatan pembelajaran dengan menggunakan MMR, guru melibatkan gambar (menggambar di papan tulis ataupun gambar yang telah tersedia).

Selain itu dalam kegiatan refleksi, guru seringkali mengajak siswa untuk melakukan tindakan atau gerakan-gerakan yang terkait dengan isi teks deposit. Dalam pelaksanaan tindakan di kelas IV ini, guru juga memerlukan kemampuan isyarat yang cukup. Karena siswa belum terbiasa berkomunikasi menggunakan oral sehingga diperlukan isyarat pada masa penyesuaian pembelajaran menggunakan MMR.

Berdasarkan hasil penelitian yang dilakukan mulai dari tes kemampuan awal, evaluasi pada siklus I, sampai evaluasi siklus II menunjukkan adanya peningkatan hasil kemampuan membaca pemahaman sesuai dengan yang diharapkan. Hasil yang diperoleh merupakan tes tertulis dengan membandingkan antara tes kemampuan awal dengan evaluasi siklus I; tes kemampuan awal dengan evaluasi siklus II; evaluasi siklus I dengan evaluasi siklus II; dan tes kemampuan awal dengan evaluasi siklus I dan siklus II. Perbandingan hasil dilakukan untuk menunjukkan bahwa adanya peningkatan pada kemampuan membaca pemahaman siswa dengan penerapan MMR pada siswa dengan hambatan pendengaran kelas IV di SLB lokasi penelitian.

Pada penelitian ini, MMR membantu siswa untuk menentukan materi pembelajaran melalui percakapan yang dilakukan bersama-sama. Dalam hal ini guru harus bisa menangkap apa yang diungkapkan anak serta dapat melakukan peran ganda. Sehingga apa yang diungkapkan siswa dapat dipahami bersama dan memudahkan siswa dalam memahami pembelajaran yang sedang berlangsung. Hal ini sejalan dengan apa yang diungkapkan pada buku "Didaktik Metodik Pemerolehan Kemampuan Berbahasa Anak Tunarungu Sekolah Dasar" yang ditulis oleh Tim Guru SLB B Pangudi Luhur, yang menjelaskan bahwa inti dari MMR adalah percakapan (Tim Guru SLBB Pangudi Luhur, 2013).

Dalam kegiatan percakapan tersebut, siswa dapat memunculkan gagasan-gagasan yang akan dijadikan topik atau materi pembelajaran. Gagasan yang dimunculkan oleh siswa dapat diperbaiki kalimatnya oleh guru. Agar lebih mudah dipahami dan dimengerti oleh semua siswa, maka guru perlu menangkap ungkapan siswa dan melakukan peran ganda. Menangkap ungkapan mengartikan bahwa guru memperhatikan, memahami, menafsirkan, dan melambangkan apa yang hendak dikatakan siswa. Sedangkan berperan ganda, berarti guru berperan sebagai siswa, bertugas membetulkan dan membahasakan ungkapan siswa dan sebagai guru bertugas menanggapi apa yang disampaikan siswa dengan pertanyaan, jawaban, sanggahan, serta provokasi. Dengan begitu, siswa akan lebih mudah memahami dan mengingat materi pembelajaran

Penggunaan bahasa yang sederhana serta gagasan-gagasan sederhana yang diungkapkan oleh siswa menjadikan siswa dapat lebih mudah memahami dan mengingat pembelajaran yang berlangsung. Pengulangan ungkapan yang dituangkan dalam kalimat-kalimat visualisasi dan teks deposit menjadikan siswa dapat lebih mudah memahami isi teks yang tersedia. Kegiatan pembelajaran yang aktif dan interaktif menjadikan suasana pembelajaran lebih menyenangkan.

Pembelajaran yang menarik akan membuat siswa lebih tertarik pula untuk fokus saat pembelajaran, sehingga materi yang diajarkan akan lebih mudah diserap oleh anak. Pembiasaaan dalam proses percami (percakapan membaca ideovisual) menjadikan siswa terbiasa untuk memahami kosa kata dalam kalimat serta memahami makna kalimat dalam suatu bacaan. Sehingga saat siswa diberikan pertanyaan yang berkaitan dengan suatu bacaan, maka siswa akan lebih mudah dalam menjawabnya.

Dalam penelitian ini, MMR mampu meningkatkan kemampuan membaca pemahaman karena bahasa yang digunakan sederhana dan materi serta bahan bacaan atau teks yang dibuat dalam 
pembelajaran merupakan hasil dari percakapan yang gagasannya diungkapkan sendiri oleh siswa. Sehingga isi bacaan tersebut telah dialami bersama oleh semua siswa dan membuat siswa menjadi lebih mudah dalam berlatih meningkatkan kemampuan membaca pemahaman terhadap suatu bacaan. Hal ini juga diperkuat oleh penelitian sebelumnya oleh Rizkia (2014) yang menyatakan bahwa adanya peningkatan yang signifikan pada kemampuan membaca pemahaman siswa hambatan pendengaran setelah dilakukan pembelajaran dengan menggunakan MMR karena dapat memberikan pengalaman langsung kepada siswa sehingga pembelajaran mudah dipahami. Berdasarkan hasil yang telah dipaparkan, menunjukkan bahwa penerapan MMR merupakan metode yang tepat bagi pembelajaran untuk siswa dengan hambatan pendengaran dalam meningkatkan kemampuan membaca pemahaman.

\section{PENUTUP}

\section{Kesimpulan}

Berdasarkan hasil penelitian dan pembahasan, menunjukkan adanya peningkatan pada kemampuan membaca pemahaman siswa dengan hambatan pendengaran kelas IV di SLB pada lokasi penelitian ini dengan menerapkan MMR dalam kegiatan pembelajaran.

Hal ini dapat dilihat dari hasil tes kemampuan membaca pemahaman yang dilakukan mulai dari tes kemampuan awal sampai pada evaluasi siklus II. Pada hasil tes kemampuan membaca pemahaman siklus I, menunjukkan hanya 2 dari 4 siswa yang sudah mencapai Kriteria Ketuntasan Minimal (KKM) dengan nilai tertinggi yaitu 90 dan nilai terendah 60. Pada siklus II, semua siswa sudah mulai terbiasa dengan penerapan MMR dalam kegiatan pembelajaran serta guru juga menambahkan media gambar dan bantuan isyarat dalam kegiatan pembelajaran.

Hasil penelitian menunjukkan adanya peningkatan hasil pada setiap siklusnya. Hasil tes kemampuan membaca pemahaman yang diperoleh pada siklus II mendapatkan nilai 100 untuk skor tertinggi dan nilai 80 sebagai skor terendah.

Hal ini menunjukkan bahwa pada siklus II, semua siswa sudah memenuhi Kriteria Ketuntasan Minimal (KKM) yang ditentukan yaitu 70. Hal tersebut membuktikan bahwa penerapan MMR dalam pembelajaran dapat meningkatkan kemampuan membaca pemahaman siswa hambatan pendengaran di SLB.

\section{Saran}

Berdasarkan hasil penelitian yang telah dilakukan, maka terdapat beberapa saran sebagai berikut:

1. Bagi pengelola SLB, hendaknya menerapkan metode pembelajaran bahasa yang konsisten bagi siswa dengan hambatan pendengaran. Metode yang tepat bagi siswa hambatan pendengaran dalam meningkatkan kemampuan berbahasa mereka terutama dalam meningkatkan kemampuan membaca pemahaman yaitu MMR. Metode ini juga mampu meningkatkan kemampuan berbahasa siswa, sehingga penting untuk diterapkan dalam kegiatan pembelajaran. Dalam hal ini, sekolah dapat menggunakan MMR dalam kegiatan pembelajaran bagi siswa dengan hambatan pendengaran secara berkelanjutan dan memberikan pelatihan khusus tentang MMR kepada semua guru.

2. Bagi guru, hendaknya lebih aktif dalam mengajak siswa untuk memperoleh pengalaman bersama dalam meningkatkan kemampuan membaca pemahaman dengan menerapkan MMR bagi siswa. Saat pembelajaran berlangsung, guru hendaknya mengunci pintu kelas agar siswa dari kelas lain tidak mengganggu jalannya kegiatan pembelajaran. Guru juga dapat memberikan reward pada siswa yang berperilaku sesuai harapan.

3. Bagi siswa, MMR dapat membantu siswa lebih mudah dalam memahami materi pembelajaran, siswa juga akan menjadi lebih berperan aktif dalam kegiatan pembelajaran. MMR juga penting diterapkan dalam pembelajaran agar siswa lebih dapat mengoptimalkan perkembangan kemampuan berbahasa dan membaca.

4. Bagi peneliti, dapat menjadi acuan bahan kajian dalam penelitian selanjutnya.

\section{DAFTAR PUSTAKA}

Abidin, Y. (2012). Pembelajaran Membaca Berbasis Pendidikan Karakter. Bandung : PT Refika Meditama.

Budiyanto. (2018). Merancang Identifikasi, Asesmen, Planing Matriks dan Layanan Kekhususan Peserta Didik Berkebutuhan Khusus di Sekolah Inklusif. Surabaya: Jakad Publishing.

Bunawan, L. \& Yuwati, C. (2000). Penguasaan Bahasa Anak Tunarungu. Jakarta: SLB-B Santi Rama.

Harefa, F.T., Sukma, E., \& Desyandri. (2019). Pengaruh Penggunaan Strategi Directed Reading Thinking Activity (DRTA) Terhadap Kemampuan Membaca Pemahaman Siswa 
kelas V Sekolah Dasar Negeri 29 Purus. Jurnal Basicedu, 3 (2), 435-442. DOI: 10.31004/ basicedu.v3i2.24

Irwanto, F., Mega, I., \& Efrina, E. (2018). Efektivitas Metode Maternal Reflektif dalam Meningkatkan Kemampuan Bahasa Anak Tunarungu. Jurnal Pendidikan Berkebutuhan Khusus, 2 (2), 25-27. DOI: $10.24036 / j p k k . v 2 i 2.140$

Mulyatiningsih, E. (2011). Metode Penelitian Terapan Bidang Pendidikan. Yogyakarta: Alfabeta.

Rahim, F. (2008). Pengajaran Membaca di Sekolah Dasar. Jakarta: Bumi Aksara.

Rizkia, R. (2014). Peningkatan Kemampuan Membaca Pemahaman Melalui Metode Maternal Reflektif (MMR) Pada Anak Tunarung Kelas Dasar IV di SLB Negeri 2 Bantul. Skripsi Tidak Diterbitkan. Yogyakarta: UNY. Retrieved from: http:// eprints.uny.ac.id/id/eprint/56893

Santrock, J.W. (2007). Perkembangan Anak. Jakarta: Erlangga.

Somadyo, S. (2017). Strategi dan Teknik Pembelajaran Membaca. Yogyakarta: Graha Ilmu.

Tarigan, D. (1992). Keterampilan Berbicara. Bandung: Angkasa

Tarigan, H.G. (2015). Membaca Sebagai Suatu Keterampilan Berbahasa. Bandung: Angkasa

Tim Guru SLB B Pangudi Luhur. (2013). Didaktik Metodik Pemerolehan Kemampuan Berbahasa Anak Tunarungu Sekolah Dasar. Yogyakarta: Percetakan Pohon Cahaya.

Zulmiyetri. (2017). Metode Maternal Reflektof (MMR) Untuk Meningkatkan Kemampuan Bahasa Lisan Anak Tunarungu. Jurnal Konseling dan Pendidikan, 5 (2), 62-67. DOI : 10.29210/117500 
Penerapan Metode Maternal...

70 PERSPEKTIF Ilmu Pendidikan - Vol. 35 No. 1 April 2021 